\title{
PEMEROLEHAN BAHASA ANAK USIA 2,5 TAHUN: ASPEK FONOLOGIS
}

\section{LANGUAGE ACQUISITION IN 2,5 YEARS CHILDREN: PHONOLOGICAL ASPECTS}

\author{
Melati Aprilia* \\ Pendidikan Bahasa dan Sastra Indonesia, Universitas Islam Negeri Syarif \\ Hidayatullah, Indonesia \\ melati.aprilia17@mhs.uinjkt.ac.id \\ *penulis korespondensi
}

\begin{tabular}{ll}
\hline Info Artikel & ABSTRAK \\
\hline Sejarah artikel: & Penelitian ini akan membahas mengenai pemeroleh bahasa anak pada usia \\
Diterima: & 2,5 tahun. Peneliti bertujuan untuk mengetahui proses pemerolehan bahasa \\
9 Januari 2020 & seorang anak. Anak yang diteliti dalam penelitian memiliki tingkat \\
Direvisi: & pemerolehan bahasa yang cukup baik, namun jika ditinjau dari aspek \\
6 Juni 2020 & fonologis masih banyak kesalahan dalam pengucapan. Metode yang \\
Disetujui: & digunakan dalam penelitian ini adalah metode kualitatif deskriptif, yang \\
11 Juli 2020 & mana menjabarkan tentang pemerolehan bahasa anak yang ditinjau pada \\
& aspek fonologisnya. Teknik pengambilan datanya dengan metode rekam, \\
Kata kunci: & simak, dan catat. Kefasihan anak dalam pengucapan ialah unsur vokal (a, i, \\
Pemerolehan bahasa, & u, e, dan o), sedangkan unsur konsonannya masih banyak ketidak tepatan \\
fonologis, vokal, & dalam pengucapan.
\end{tabular}

konsonan

\begin{tabular}{ll}
\hline Article Info & ABSTRACT \\
\hline $\begin{array}{l}\text { Article history: } \\
\text { Received: }\end{array}$ & $\begin{array}{l}\text { This study will discuss about the acquisition of 2,5 years old children's } \\
\text { language. Researchers aim to determine the process of language acquisition } \\
\text { ofanuary } 2020\end{array}$ \\
$\begin{array}{l}\text { Revised: } \\
\text { language acquisition, but when viewed from the phonological aspect there }\end{array}$ \\
$\begin{array}{l}\text { Accepted: } \\
\text { 11 July 2020 }\end{array}$ & $\begin{array}{l}\text { is descriptive qualitative method, which describes the acquisition of } \\
\text { children's language in terms of phonological aspects. The technique of } \\
\text { collecting data using the recording method, observe, and note. Children's } \\
\text { Keyword: }\end{array}$ \\
$\begin{array}{l}\text { fluency in pronounciation is the vocal element (a, i, u, e, and o), while the } \\
\text { phonology, } \\
\text { vocal, consonants }\end{array}$ & consonant elements are still many inaccuracies in pronounciation. \\
\end{tabular}

\section{PENDAHULUAN}

Pemerolehan bahasa anak dimulai ketika orang tua mengajak berbicara (berkomuniasi) lewat bahasa. Orang tua mengajak bayi berbicara dengan alih-alih beranggapan bahwa bayi sudah mampu berkomunikasi. Komunikasi bahasa yang dihasilkan oleh seorang bayi dapat berupa ocehan- ocehan atau babbling. Bahasa yang diperoleh seorang anak yang baru lahir (bayi) yaitu dari ibunya. Setelah bertumbuh menjadi balita, seorang anak akan memperoleh bahasa bukan hanya dari ibunya, tetapi juga dari orang-orang yang berada di sekitarnya. Orang-orang disekitar dapat mempengaruhi pemerolehan bahasa 
seorang anak. Pada saat bayi seorang anak akan menggunakan bahasa isyarat (tangisan) untuk mengungkapkan keinginanya, seperti saat lapar, haus, dan buang air. Ketika seorang anak sudah beranjak balita, maka bahasa yang telah diperolehnya dijadikan alat untuk mengungkapkan keinginan, perasaan, dan pikirannya dalam melakukan tindak komunikasi.

Bahasa yang diperoleh seorang anak pertama kali adalah bahasa ibu atau bahasa pertama. Bahasa ini menjadi tonggak awal seorang anak melakukan tindak komunikasi. Bahasabahasa yang diucapkannya mulai dipahami oleh orang lain. Bahasa yang diucapkan seorang anak balita tentu tidak sefasif orang dewasa, terkadang masih banyak kesalahan dalam pengucapannya.

Kesalahan pengucapan atau pelafalan seorang anak dapat ditinjau berdasarkan aspek fonologis. Pemerolehan bahasa seorang anak dapat berupa pemerolehan bahasa pertama atau pemerolehan bahasa kedua. Pemerolehan bahasa anak pertama dapat berupa bahasa sederhana menuju wujud bahasa yang lebih rumit. Penerimaan seorang anak dalam proses pemerolehan bahasa sejalan dengan perkembangan biologisnya, khususnya yang berkaitan dengan alat pengucapannya. Hal ini yang menjadi dasar perbedaan para anak dalam pemerolehan bahasanya walaupun dimasa usia yang sama.

Lebih daripada itu, suatu pemerolehan bahasa anak sangat menarik untuk diteliti, yang mana peneliti akan mengetahui variasi katakata yang diucapkan seorang anak dengan tingkat ketepatan yang tidak sama sekali sama dengan pemerolehannya. Menurut Krashen (1983:1-2), pemerolehan merupakan suatu proses amabng sadar seseorang yang identik dengan suatu proses yang dilalui manusia (anak) dalam memperolah bahasa pertamanya (bahasa ibu). Pemerolehan bahasa dapat diitinjau melalui aspek apapun, misalnya aspek fonologisnya. Pemerolehan bahasa anak tidak hanya hanya dapat ditinjau pada aspek fonologisnya saja. Akan tetapi, dapat ditinjau berdasarkan pada aspek morfologi, semantik, dan aspek sintaksisnya. Aspek fonologis adalah salah satu alat yang digunakan dalam penelitian mengenai pemerolehan bahasa anak, sebab fonologis dapat melihat dari segi keteraturan, kerumitan, dan keterbatasan sistem bunyi yang dilafalkan oleh seorang anak. Aspek fonologis dapat dijadikan sebagai penyokong teori-teori linguistik yang telah dihasilkan oleh para pakar linguistik. Kajian fonologis ini dapat berfungsi untuk mengetahui kevariasian bunyi yang dihasilkan oleh seorang anak dalam berbahasa. Anak dalam kategori balita tentu sedang dalam tahap pemerolehan bahasa yang intens atau sering. Pemerolehan bahasa ini melalui tahap berskala (step by step). Pemerolehan bahasa pertama kali yang didapat seorang anak merupakan pemerolehan bahasa yang terjadi jika seorang anak yang belum pernah belajar bahasa apapun (Klein, 1984: 6).

Pemerolehan bahasa memiliki kaitan dengan proses, seperti yang dikemukakan oleh Gleason dalam Nuryani dan Dona, bahwa sebagai bagian dari pokok kajian psikolinguistik, pemerolehan bahasa (language acquisition) menjadi pusat perhatian bagi para peneliti (Nuryani dan Putra, 2013: 88). Gleason mengungkapkan pendapatnya mengenai psikolinguistik yang terutama mengkaji tiga hal utama, yaitu pertama, proses mental yang dialami 
oleh seseorang seperti dalam kegiatan mendengar, memahami, serta memngingat sesuatu yang telah didengarnya, proses ini disebut sebagai comprehension. Kedua, proses mental yang terjadi ialah ketika seseorang menyatakan sesuatu yang hendak dikatakannya, proses ini disebut sebagai production. Dan yang ketiga, prosedur atau proses mental ini diikuti anak-anak dalam belajar memahami dan memproduksi bahasa pertamanya atau disebut sebagai proses acquisition (Barko and Ratner, 1998: 4). Bagi Hamied dalam proses pemerolehan bahasa seorang anak terdapat beberapa faktor sosial yang sangat berpengaruh seperti usia, seks, kelas sosial, dan identitas etnis (Hamied, 1989: 24). Suatu pemerolehan (acquisition) diartikan sebagai istilah yang kerap kali digunakan untuk mengkaji suatu proses pemerolehan bahasa yang didapatkan seorang anak secara alami pada saat anak belajar bahasa ibu (native language) (Soenjono Dardjowidjojo, 2010: 25). Para ahli juga mengungkapkan bahwa seorang anak mendapatkan bahasa secara alamiah, tanpa adanya upaya kesadaran yang telah direncanakan. Menurut Sigel dan Cocking perumusan mengenai pemerolehan bahasa diartikan sebagai proses yang digunakan oleh anak-anak dalam menyesuaikan serangkaian hipotesis dengan lafal atau ucapan orang tua yang sampai dapat memilih kaidah kebahasaan yang paling sederhana dan paling baik (Sigel dan Cocking, 2000: 5). Pemerolehan bahasa anak dapat dijadikan dua golongan yaitu pemerolehan bahasa pertama dan pemerolehan bahasa kedua. Seperti yang dikatakan oleh Nuryani dan Dona dalam bukunya yang berudul Psikolinguistik, mereka mengungkapkan bahwa pemerolehan bahasa pertamma seorang anak terjadi jika anak tersebut belum pernah mempelajari bahasa apapun, lalu memperoleh bahasa. 'Pemerolehan ini bisa satu bahasa atau monolingual FLA (First Language Acquisition), bisa dua bahasa secara bersamaan atau berurutan (Bilingual FLA), bahkan bisa lebih dari dua bahasa (multilingual FLA) (Nuryani dan Putra, 2013: 90). Seorang anak dapat memperoleh bahasa kedua ketika anak tersebut telah menguasai bahasa pertamanya terlebih dahulu. Salah satu faktor penentu keberhasilan pemerolehan bahasa pada anak yaitu terletak pada aspek bilogis dan aspek sosial. Selain itu, faktor intelegensi juga dapat mempengaruhi seorang anak dalam memperoleh bahasa. Menurut Arsanti dalam bukunya menyatakan bahwa pemerolehan bahasa atau (language acquisition) adalah suatu proses ketika anak mendapatkan bahasa pertamanya (Arsanti, 2014: 25).

Setiap anak dalam pemerolehan bahasa memiliki tahap masing-masing, seperti yang kita ketahui ketika anak bayi mulai bisa mengucapkan kata-kata pertama kali biasanya berupa kata "cucu" dan "mamama". Masa ini sering dikenal dnegan sebutan canonical. Seorang anak mampu mengucapkan kosa kata bahasanya pertama kali biasanya kurang dari usia satu tahun. Akan tetapi, bahasa yang diungkapkan oleh seorang anak biasanya belum memiliki makna. Ingram (Nuryani \& Putra, 2013: 91-92) mengemukakan bahwa tahah pemerolehan bahasa anak terbagi menjadi empat tahap yaitu; (1) Tahap Pralinguistik (0-12 bulan), (2) Tahap satu-kata (12-18 bulan), (3) Tahap dua kata (18-24 bulan), dan (4) Tahap banyak kata (3-5 tahun). Menurut Chaer (Natsir, 2017: 21), pemerolehan bahasa berarti suatu proses yang teradi 
dalam otak anak-anak ketika memperoleh bahasa pertama atau bahasa mama. Kusuma dalam bukunya menyebutkan bahwa penguasaan bahasa seorang anak diperoleh secara alamiah, dan secara tidak sadar terjadi dalam lingkungan keluarga anak-anak tersebut (Kusuma, 2016: 120).

Secara teoritis, pemerolehan bahasa dapat digolongkan berdasarkan tiga teori, yaitu teori behavioristik, teori mentalistik, dan teori kognitif. Brown (Pateda, 1990: 43) menyatakan bahwa seorang anak yang terlahir di dunia diibaratkan sebagai kain putih tanpa adanya catatan-catatan, yang mana dapat dibentuk oleh lingkungan secara perlahan-lahan, dan dikondisikan, serta adanya pengukuhan terhadap prilaku seseorang. Selain itu, Skinner (Suhartono, 2005: 73) mengatakan bahwa tingkah laku bahasa seseorang dapat dilakukan dengan cara penguatan. Penguatan ini terjadi dengan adanya proses stimulus dan respon. Selanjutnya, teori mentalistik berpandangan bahwa proses pemerolehan bahasa bukan dipengaruhi hasil belajar tingkah laku, tetapi lebih pada potensi bahasa yang akan berkembang sesuai dengan proses perkembangan intelektualnya. Chomsky (Nuryani \& Putra, 2013: 103) mengemukakan bahwa anak yang telah lahir ke dunia pasti membawa kapasitas atau potensi masing-masing. Potensi bahasa ini turut membantu dalam menentukan struktur bahasa yang segera digunakan. Lain daripada itu, teori kognitif memandang bahasa secara lebih dalam. Pemerolehan bahasa ini dapat memanfaatkan aspek fonologis. Aspek fonologis memang biasanya digunakan dalam fase anak usia 0-2 tahun, yang mana pada tahap ini seorang anak sednag menghasilkan banyak bunyi bahasa dan sampai pada tahap mengoceh atau babbling dengan kata yang sangat sederhana. Dengan demikian, maka pemerolehan bahasa pada anak adalah suatu proses bagaimana anak mampu menyerap bahasa ibu secara alamiah yang disesuaikan dengan perkembangan kognitifnya, interkasi sosialnya, perkembangan linguistiknyan terutama pada aspek fonologisnya.

Pada penelitian ini akan dijelaskan lebih dalam mengenai pemerolehan bahasa anak usia 2,5 tahun dilihat dari aspek fonologisnya. Pemerolehan bahasa anak didapat dari keluarga dan lingkungan sekitarnya secara intens. Dalam menganalisis pemerolehan bahasa peneliti akan memaparkan dengan cara menganalisis aspek fonologis pada anak. Tujuan dari dibuatnya sebuah penelitian ini tentu untuk menjelaskan kepada para pembaca dalam mengetahui kosa kata apa saja yang telah diperoleh oleh seorang anak di usia 2,5 tahun ditinjau dari aspek pengucapan atau pelafalannya. Penguasaan dalam pengucapan huruf vokal dan konsonan.

\section{METODE}

Penelitian ini menggunakan metode kualitatif deskriptif. Metode deskriptif diartikan sebagai suatu metode penelitian yang menjelaskan peristiwa atau fenomena yang sedang terjadi (Noor, 2011: 34). Pada penelitian ini menggunakan teknik literatur (kajian pustaka). Buku, jurnal, dan laporan dijadikan sebagai bahan yang berkaitan dengan kajian psikolinguistik ini, khususnya mengenai "pemerolehan bahasa anak ". Teknik dalam penelitian ini bertujuan untuk memaparkan berbagai teori-teori yang relevan dengan sub permasalahan pada penelitian ini. Teknik pengumpulan data yaitu dengan 
merekam video atau suara dari anak yang bernama Naira pada usia 2,5 tahun, data ini merupakan data primer. Sedangkan, data sekunder diperoleh dari berbagai rujukan buku dan jurnal yang terkait pada penelitian ini. Merekam kegiatan anak tersebut, dilakukan ketika ia sedang berbicara dengan ibunya, kakaknya, dan ayahnya, selain itu juga ketika ia berinteraksi dengan orang lain. Dari adanya teknik ini peneliti menjadikan sebagai rujukan dalam pembahasan hasil penelitian.

Sumber-sumber yang dihasilkan dari rekaman, catat, dan simak guna menjawab permasalahan dalam penelitian ini, sehingga mampu menghasilkan tulisan ilmiah yang sistematis. Teknik simak dalam penelitian ini digunakan saat menyimak rekaman berupa suara dan video, serta menstranskip data dengan teknik catat. Sumber data primer dalam penelitian ini ialah rekaman sebagai sampel penelitian yang akan dijabarkan dalam pembahasan. Dan langkah selanjutnya ialah pengolahan informasi data menjadi sebuah kalimat analisis yang sesuai dengan pembahasan pada penelitian ini.

\section{HASIL DAN PEMBAHASAN}

Pada penelitian ini sumber data informasi berpusat pada objek yaitu seorang anak perempuan bernama Naira Nazla Azkadina. Naira lahir di
Tangerang Selatan pada tangggal 20 April 2017. Naira tumbuh menjadi gadis cilik yang sehat secara fisik dan mental. Dalam kesehariannya Naira seorang gadis cilik yang berusia 2,5 tahun hidup dalam keluarga yang harmonis, ramai, dan bersih. Orang tua dari Naira berpendidikan strata SI, sehingga bahasa yang diperoleh oleh Naira terutama dari orang tuanya cukup memenuhi tata bahasa Indonesia yang baik. Setiap harinya Naira tidak hanya berinterkasi dengan orang tuanya saja, tetapi juga berinteraksi dengan kakaknya yang bernama Naila, kakak sepupunya yang bernama, dinda, dillah, dan fatimah, serta tantenya yang bernama Erna. Naira tinggal dalam keluarga besar, sehingga interaksinya setiap hari terjadi cukup sering, hal ini meningkatkan kualitas penguasaan bahasa oleh Naira. Selain itu, Niara sering diajak pergi oleh orang tuanya untuk berkunjung ke tempat saudara, dan juga terkadang berkunjung ke tempat ibunya mengajar. Bahkan, hampir setiap hari minggu Naira diajak berjalan keliling komplek perumahannya. Maka dari itu, pemerolehan bahasanya cukup beragam. Berikut pemerolehan bahasa pada Naira yang dianalisis dari aspek fonologisnya. Berikut data dan penjelasannya. 
Aprilia/Pemerolehan Bahasa Anak Usia 2,5 Tahun...

Stilistika: Jurnal Pendidikan Bahasa dan Sastra Vol.13, No. 2, Juli 2020 Hal 186-197

Tabel 1 Data Pemerolehan Bahasa Naira

\begin{tabular}{|c|c|c|c|c|c|}
\hline No. & Bunyi & Konteks & Data & & Keterangan \\
\hline 1. & Vokal /a/ & $\begin{array}{l}\text { Ketika Naira sedang } \\
\text { makan permen }\end{array}$ & $\begin{array}{ll}\text { Bunda: } & \text { Bagi dong! } \\
\text { Naira: } & \text { nggak. } \\
& \text { (enggak). } \\
\text { Bunda: } & \text { Buat Ayah ada? } \\
\text { Naira: } & \text { Ada. } \\
\text { Naila: } & \text { Buat Kakak ada de? } \\
\text { Naira: } & \text { nggak ada tatak mah. } \\
& \text { (enggak, kakak) }\end{array}$ & 2) & $\begin{array}{l}\text { Vokal /a/ } \\
\text { (depan): /a/, /d/, } \\
\text { /a/ } \\
\text { Vokal /a/ } \\
\text { (tengah): /n/, /g/, } \\
/ \mathrm{g} /, / \mathrm{a} /, / \mathrm{k} / . / \mathrm{t} /, \\
/ \mathbf{a} /, / \mathrm{t} /, / \mathrm{a} /, / \mathrm{k} / . \\
/ \mathrm{m} /, / \mathrm{a} /, / \mathrm{h} / . \\
\text { Vokal /a/ } \\
\text { (akhir): /a/, /d/, } \\
\text { /a/. }\end{array}$ \\
\hline 2. & Vokal /i/ & $\begin{array}{l}\text { Ketika Naira meminta } \\
\text { tolong kepada } \\
\text { pamannya untuk } \\
\text { membukakan bungkus } \\
\text { permen }\end{array}$ & $\begin{array}{l}\text { Paman: Kalo minta tolong bilangnya gimana? } \\
\text { Naira: } \quad \text { Butain. } \\
\text { Paman: Bilang apa kalau sudah dibantuin? } \\
\text { Naira: Makacih, Om. } \\
\text { Bunda: permennya rasa apa Nai? } \\
\text { Naira: rasa Stobeyyi. } \\
\quad \text { (Strawberry) }\end{array}$ & 2) & $\begin{array}{l}\text { Vokal /i/ } \\
\text { (tengah): /b/, /u/, } \\
/ \mathrm{t} /, / \mathrm{a} /, / \mathrm{i} /, / \mathrm{n} / . \\
/ \mathrm{m} /, / \mathrm{a} /, / \mathrm{k} /, / \mathrm{a} /, \\
/ \mathrm{c} /, / \mathrm{i} /, / \mathrm{h} / . \\
\text { Vokal /i/ (akhir): } \\
/ \mathrm{s} /, / \mathrm{t} /, / \mathrm{o} /, / \mathrm{b} /, / \mathrm{y} /, \\
/ \mathrm{y} /, / \mathrm{i} / .\end{array}$ \\
\hline 3. & Vokal /u/ & $\begin{array}{l}\text { Ketika Naira } \\
\text { menyanyi sendiri }\end{array}$ & $\begin{array}{l}\text { Naira: Molehkah pagi daku menancitamu } \\
\text { yang dulu mencintakamu dayaan yang } \\
\text { mungkin acimu, hingga kau kika kakitiku } \\
\text { yang beyum mencinta kali dalam aaaaaa. } \\
\text { (bolehkah pagi aku menantimu yang dulu } \\
\text { mencintai kamu kaya dan yang mungkin } \\
\text { hatimu, hingga kau siksa hatiku yang belum } \\
\text { mencintai kali dalam..) }\end{array}$ & 1) & 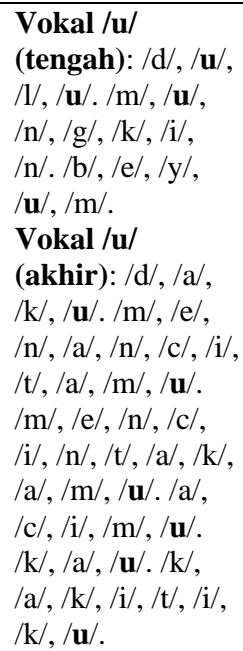 \\
\hline 4. & Vokal /e/ & $\begin{array}{l}\text { Ketika Naira sedang } \\
\text { berbicara pada } \\
\text { kakaknya. Dan ketika } \\
\text { Naira sedang bermain } \\
\text { dengan kawan- } \\
\text { kawannya. }\end{array}$ & $\begin{array}{l}\text { Naira: Tatak itu ada satu agi, itu jinji. } \\
\text { Naila: Apa itu jinji? } \\
\text { Naira: Jinji itu yang ada kolam benang. } \\
\text { Naila: Di kolam renang ada apa? } \\
\text { Naira: Kobing. (kepiting). } \\
\text { Kawan Naira: Hompimpa alaium gambreng. } \\
\text { Naira: (tertawa) aku menyang. }\end{array}$ & 1) & $\begin{array}{l}\text { Vokal /e/ } \\
\text { (tengah): /b/, /e/, } \\
/ \mathrm{n} /, / \mathrm{a} /, / \mathrm{n} /, / \mathrm{g} / \\
/ \mathrm{m} /, / \mathrm{e} /, / \mathrm{n} /, / \mathrm{y} /, \\
/ \mathrm{a} /, / \mathrm{n} /, / \mathrm{g} / .\end{array}$ \\
\hline 5. & Vokal /o/ & $\begin{array}{l}\text { Ketika Naira sedang } \\
\text { membuat vlog ala } \\
\text { para youtuber dengan } \\
\text { kakak sepupunya }\end{array}$ & $\begin{array}{l}\text { Fatimah: Halo Bunda, gitu. } \\
\text { Naira : Bunda gak ada. } \\
\text { Fatimah: Halo Bunda } \\
\text { Naira : Bunda mana? Ooo bunda mo } \\
\text { nonton. } \\
\text { Fatimah: Mau nonton apa? } \\
\text { Naira: Mo nonton moo (youtube). } \\
\text { (Lalu ia merengek kepada bundanya) bunda } \\
\text { aku mo nonton moo (youtube) }\end{array}$ & 1) & $\begin{array}{l}\text { Vokal /o/ } \\
\text { (tengah): /n/,/o/, } \\
/ \mathrm{n} /, / \mathrm{t} /, / \mathbf{l o} /, / \mathrm{n} / . \\
\text { Vokal /o/ } \\
\text { (akhir): /m/, /o/. } \\
/ \mathrm{m} /, / \mathrm{o} /, / \mathbf{o} / .\end{array}$ \\
\hline
\end{tabular}




\begin{tabular}{|c|c|c|c|c|c|}
\hline No. & Bunyi & Konteks & Data & & Keterangan \\
\hline 6. & $\begin{array}{l}\text { Konsonan } \\
\text { /b/ dan /d/ }\end{array}$ & $\begin{array}{l}\text { Ketika Naira } \\
\text { menanyakan } \\
\text { bundanya dan } \\
\text { meminta untuk } \\
\text { menonton youtube }\end{array}$ & $\begin{array}{l}\text { Fatimah: Halo Bunda, gitu. } \\
\text { Naira : Bunda gak ada. } \\
\text { Fatimah: Halo Bunda } \\
\text { Naira : Bunda mana? Ooo bunda mo } \\
\text { nonton. } \\
\text { Fatimah: Mau nonton apa? } \\
\text { Naira: Mo nonton moo (youtube). } \\
\text { (Lalu ia merengek kepada bundanya) bunda } \\
\text { aku mo nonton moo (youtube) }\end{array}$ & 1) & $\begin{array}{l}\text { Konsonan /b/ } \\
\text { dan /d/ (awal } \\
\text { dan tengah): /b/, } \\
/ \mathrm{u} /, / \mathrm{n} /, / \mathbf{d} /, / \mathrm{a} / . \\
/ \mathrm{a} /, / \mathrm{d} /, / \mathrm{a} / .\end{array}$ \\
\hline 7. & $\begin{array}{l}\text { Konsonan } \\
/ \mathrm{m} / \text { dan } \\
/ \mathrm{n} /\end{array}$ & $\begin{array}{l}\text { Ketika Naira } \\
\text { berbicara pada uwa } \\
\text { nya (kakak dari } \\
\text { bundanya) dengan } \\
\text { cara meniru lagu } \\
\text { Jhony-jhony Yes Papa }\end{array}$ & $\begin{array}{l}\text { Naira: Mamah, Mamah. } \\
\text { Uwa : Yes, Naira. } \\
\text { Naira : Makan naci? (nasi) } \\
\text { Uwa : Enggak boleh. } \\
\text { Naira: Babahan? (semacam gorengan ) } \\
\text { Uwa: Enggak boleh. } \\
\text { Naira: Bunda makan bawan mulu. (bakwan) } \\
\text { Uwa : Kenapa? } \\
\text { Naira: Makan bawan mulu. } \\
\text { Uwa : Siapa yang makan bakwan mulu? } \\
\text { Naira: Mamah } \\
\text { Uwa : Kagak. } \\
\text { Naira: Emang. } \\
\text { Uwa : Ngkritik terus, ahh. }\end{array}$ & 1) & 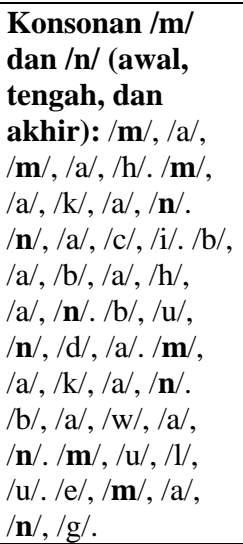 \\
\hline 8. & $\begin{array}{l}\text { Konsonan } \\
\text { /g/ dan /s/ }\end{array}$ & $\begin{array}{l}\text { Ketika Naira sedang } \\
\text { bermain dengan } \\
\text { Saudaranya yang ia } \\
\text { panggil sebagai kak } \\
\text { ambon }\end{array}$ & $\begin{array}{l}\text { Naira : ni jempol tembako lima ratus, } \\
\text { mononet, mononet, tak Ambon mau } \\
\text { apa? (ini jempol, sembako lima } \\
\text { ratus, mononet mononet, kak } \\
\text { Ambon mau apa? } \\
\text { Kak Ambon: Aku mau manggis. } \\
\text { Naira : Manggis? } \\
\text { Kak Ambon: Iya. }\end{array}$ & 1) & $\begin{array}{l}\text { Konsonan /g/, } \\
\text { dan } / \mathbf{s} / \text { (tengah } \\
\text { dan akhir): /m/, } \\
/ \mathrm{a} /, / \mathrm{n} /, / \mathrm{g} /, / \mathrm{g} /, / \mathrm{i} / \text {, } \\
/ \mathrm{s} / .\end{array}$ \\
\hline 9. & $\begin{array}{l}\text { Konsonan } \\
/ \mathrm{h} / \text { dan } / \mathrm{y} /\end{array}$ & $\begin{array}{l}\text { Ketika Naira sedang } \\
\text { menonton youtube } \\
\text { dan pamannya } \\
\text { menanyakan } \\
\text { mengenai warna- } \\
\text { warna yang ada dalam } \\
\text { youtube tersebut }\end{array}$ & $\begin{array}{l}\text { Paman: Nai ini warna apa? } \\
\text { Naira : Hijo. (hijau) } \\
\text { Paman: Kalau yang ini Nai? } \\
\text { Naira : Merlah. (Merah). } \\
\text { Paman: Permennya rasa apa Nai? } \\
\text { Naira : Meyon. (melon) } \\
\text { Paman: Enak ya, Nai. }\end{array}$ & 2) & $\begin{array}{l}\text { Konsonan } / \mathrm{h} / \\
\text { dan } / \mathrm{y} /(\text { awal, } \\
\text { tengah, dan } \\
\text { akhir): /h/, /i/, /j/, } \\
/ \mathrm{o} / . / \mathrm{m} /, / \mathrm{e} /, / \mathrm{r} /, \\
/ \mathrm{l} /, / \mathrm{a} /, / \mathrm{h} / . / \mathrm{m} /, \\
/ \mathrm{e} /, / \mathrm{y} /, / \mathrm{o} /, / \mathrm{n} / .\end{array}$ \\
\hline
\end{tabular}

Berdasarkan data di atas maka pemerolehan bahasa Naira dapat dianalisis sebagai berikut.

\section{Pemerolehan vokal [a]}

Pada percakapan dalam data yang terjadi dialog antara Bunda dengan Naira dan Kakak dengan Naira. Ketika Naira sedang asik makan permen, bundanya meminta permen tersebut, tetapi Naira tidak ingin membagi permen tersebut sehingga ia melafalkan kata "nggak" yang terdiri dari fonem /n/, /g/, /g/, /a/, /k/. dalam kata tersebut
Naira menguasai bunyi vokal [a] yang berposisi di akhir kata dengan cukup baik. Kemudian, ketika Bundanya bertanya mengenai jatah untuk ayahnya ada atau tidak, Naira melafalkan kata "Ada" yang terdiri dari fonem /a/, /d/, /a/. hal ini menandakan bahwa Naira mampu menguasai posisi fonem /a/ yang berada di awal dan di akahir kata. Pada kata "tatak" yang terdiri dari fonem /t/, /a/, /t/, /a/, /k/, Naira mampu menguasai kata yang vokal [a] menduduki posisi tengah. Dapat kita ketahui dari data di atas bahwa bunyi 
vokal [a] merupakan bunyi utama yang dikuasai oleh Naira secara utuh. Bunyi vokal [a] tersebut dilafalkannya dengan jelas, baik vokal [a] yang berada di awal, tengah, ataupun akhir pada kata.

\section{Pemerolehan vokal [i]}

Pada percakapan dalam data terjadi dialog antara Paman dengan Naira dan Bunda dengan Naira. Ketika Naira sedang berusaha membuka bungkus permennya, dan ketika sudah capek membukanya tapi tidak bisa juga, ia akhirnya memberikan pada pamannya tanpa berbicara. Lalu, pamannya meminta dia untuk bilang minta tolong, dan Naira menjawab dengan lafal "bukain". Kata "bukain" terdiri dari fonem /b/, /u/, /k/, /a/, /i/, /n/. dalam kata tersebut Naira mengusai bunyi vokal [i] yang berada di akhir kata. Kemudian, pelafalan vokal [i] juga terlihat dari percakapan ketika ia bilang terima kasih dengan pelafalan "makacih" yang terdiri darri fonem $/ \mathrm{m} /, / \mathrm{a} /, / \mathrm{k} /, / \mathrm{a} /, / \mathrm{c} /$, /i/, /h/ pada pamannya dan menjawab pertanyaan dari bundanya mengenai rasa permen tersebut yaitu rasa Strawberry, ia melafalkan kata "sobeyyi" yang terdiri dari fonem /s/, /t/, /o/, /b/, /e/, /y/, /y/, /i/. Naira sudah memperoleh bunyi vokal [i] dengan baik dan mampu melafalkan fonem /i/ yang berposisi baik diawal, tengah, maupun akhir. Seperti yang telah kita ketahui, bahwa Naira mampu menguasai vokal [i] dengan baik dan benar.

\section{Pemerolehan vokal [u]}

Pada data adalah ketika Naira sedang asik bernyanyi sendiri. Naira menyanyi berdasarkan hasil dari pemerolehan bahasa yang ia dapat. Pemerolehan yang ia dapat tentu ketika dia mendengarkan sebuah lagu, sehingga lirik lagu tersebut terserap dalam otak Naira. Walaupun Naira tidak begitu mengerti apa yang ia nyanyikan dan ia ucapkan, yang ia tahu adalah itu sebuah lagu dan bisa dinyanyikan. Jika ditinjau dari aspek fonologis, dari tuturan Naira tersebut, ia telah memperoleh fonem /u/, pada kata "daku", "menancitamu", "dulu", "mencintakamu", "mungkin", "acimu”, "kau", "kakitiku", dan "beyum". Kata "daku" terdiri dari fonem /d/, /a/, /k/, /u/. Kata "menancitamu" terdiri dari fonem $/ \mathrm{m} /$, /e/, /n/, /a/, /n/, /c/, /i/, /t/, /a/, $/ \mathrm{m} /, \mathrm{u} /$. Kata "dulu" terdiri dari fonem /d/, /u/, /1/, /u/. Kata "mencintakamu" terdiri dari fonem $/ \mathrm{m} /, / \mathrm{e} /, / \mathrm{n} /, / \mathrm{c} /, / \mathrm{i} /$, $/ \mathrm{n} /, / \mathrm{t} /, / \mathrm{a} /, / \mathrm{k} /, / \mathrm{a} /, / \mathrm{m} /, / \mathrm{u} /$. Kata "mungkin" terdiri dari fonem $/ \mathrm{m} /, / \mathrm{u} /$, /n/, /g/, /k/, /i/, /n/. Kata "acimu" terdiri dari fonem /a/, /c/, /i/, /m/, /u/. Kata "kau" terdiri dari fonem $/ \mathrm{k} /, \mathrm{a} /, \mathrm{u} /$. Kata "kakitiku" terdiri dari fonem $/ \mathrm{k} /$, /a/,/k/, /i/, /t/, /i/, /k/, /u/. Kata "beyum" terdiri dari fonem /b/, /e/, /y/, /u/, /m/. Jika dilihat dari data di atas maka dapat disimpulkan bahwa Naira mampu menguasai vokal $[\mathrm{u}]$ yang ia peroleh dari seringnya mendengarkan lagu tersebut yang dinyanyikannya. Penguasaan vokal [u] Naira cukup baik karena ia menguasai vokal [u] baik yang terletak di awal, tengah, maupun akhir pada sebuah kata. Vokal [u] yang terletak di tengah seperti pada kata, "mungkin", dan "beyum". Vokal [u] yang terletak pada akhir kata seperti pada kata, "daku", "menancintamu", "dulu", "mencintakamu", "kau", "acimu", dan "kakitiku".

\section{Pemerolehan vokal [e]}

Pada percakapan dalam data bahwa Naira sedang melakukan percakapn dengan kakaknya yaitu Naila. Saat itu Naira memberitahukan kepada kakaknya bahwa ada "jinji”, lalu kakaknya menanyakan apa itu "jinji". 
Dan Naira menjawab jinji ada dalam kolam renang dalam lafal "kolam benang". Kata "benang" berarti renang. Kata "benang" terdiri dari fonem $/ \mathrm{b} /$, /e/, /n/, /a/, /n/, /g/. Naira Melafalkan fonem /e/ pada kata "benang" baik dan lugas. Selain itu, Naira ketika sedang bermain dengan mengucapkan kata "menyang" yang berarti menang. Kata "menyang" terdiri dari fonem $/ \mathrm{m} /, \mathrm{e} /$, /n/, /y/, /a/, /n/, /g/. dalam kata tersebut juga melafalkan fonem /e/ dengan baik dan lugas. Fonem /e/ memang mudah untuk diucapkan oleh anak seusia Naira sebab tidak mempersulit pemerolehan bunyi yang dikeluarkan dan tidak mempersulit alat berbicaranya. Bunyi vokal [e] yang diucapkan Naira hanya terletak pada titik tengah sebuah kata berdasarkan data di atas.

\section{Pemerolehan vokal [o]}

Pada percakapan dalam data terjadi konteks dimana Naira dan kakak sepupunya sedang membuat video vlog ala para youtuber. Kaka sepupunya memulai dengan sapaan kepada bundanya Naira. Lalu, Naira menjawabnya. Ketika sedang asik membuat video tersebut tiba-tiba Naira meminta untuk menonton youtube kepada bundanya. Naira menyebut aplikasi Youtube dengan sebutan Moo. Berdasarkan keterangan yang peneliti dapat dari bundanya, Naira menyebut Moo sebab pertama kali ia menonton youtube yang ditonton adalah kartun hewan (sapi) yang suka mengeluarkan suara Moo. Sehingga kesan pertama yang diterima oleh Naira adalah youtube berarti bernama Moo. Dari konteks di atas terlihat bahwa Naira menguasai vokal [o] dalam pengucapannya, seperti kata "mo" yang berarti mau. Kata "mo" terdiri dari fonem $/ \mathrm{m} /$, /o/. selain itu, Naira juga mengucapkan kata "nonton" dengan fasih. Kata "nonton" terdiri dari fonem $/ \mathrm{n} /, / \mathrm{o} /, / \mathrm{n} /, / \mathrm{t} /, / \mathrm{o} /, / \mathrm{n} /$. Naira dapat menguasai vokal [o] dengan baik dan lugas dalam pengucapannya. Vokal [o] yang diucapkan Naira berdasarkan data di atas pada fonem /o/ hanya terletak di tengah dan akhir sebuah kata.

Berdasarkan pada data dan analisis di atas maka Naira bisa dikatakan cukup menguasai bunyi-bunyi vokal bahasa Indonesia dengan baik dan benar. Vokal yang obek kuasai yaitu [a], [i], [u], [e], dan [o]. Bunyi vokal tersebut ada yang terdapat pada awal kata, tengah kata, ataupin akhir kata. Variasi bunyi vokal tersebut telah dikuasai oleh Naira dari hasil pemerolehan bahasa di lingkungan keluarga dan lingkungan sekitar. Setiap harinya Naira dapat berinteraksi dengan keluarganya baik bunda, ayah, kakak, atau kakak sepupunya. Bahkan juga Naira berinteraksi dengan kawan bermainnya. Dari bentuk-bentuk interaksi tersebutlah yang menjadi wadah pemerolehan bahasa Naira. Selain pemerolehan bahasa Naira dari segi pemerolehan vokal, juga terdapat pemerolehan bahasa dari segi konsonan. Pemerolehan konsonan dijelaskan sebagai berikut.

\section{Pemerolehan konsonan [b] dan [d]}

Pada percakapan dalam data dapat diketahui bahwa Naira memanggil bundanya dan meminta untuk menonton youtube yang ia sebut sebagai moo. Pelafalan Naira pada kata "bunda" yang terdiri dari fonem $/ \mathrm{b} /, \mathrm{u} /$, /n/, /d/, /a/ cukup jelas. Bunyi konsonan /b/ dan/b/ merupakan bunyi bilabial. Naira mampu mengutarakan bunyi bilabial /b/ dan /d/ dengan jelas. Maka dalam hal ini Naira mampu memperoleh bunyi letupan bilabial dengan sangat jelas tanpa ada gangguan dalam pengucapannya. Pemerolehan 
bahasa Naira pada kata "bunda" cukup menghasilkan bunyi letupan bilabial yang jelas terutama pada konsonan $[\mathrm{b}]$ dan $[\mathrm{d}]$.

\section{Pemerolehan konsonan [m] dan [n]}

Pada percakapan dalam data konteks pembicaraan tersebut adalah ketika Naira meminta makan nasi atau gorengan, tetapi uwanya tidak memberikan, sebab Naira sudah makan 30 menit yang lalu. Naira meminta makan sebab ia melihat Uwa nya yang sedang asik makan gorengan bakwan, sehingga Naira ingin makan lagi. Namun, Uwa nya tidak memberikan sebab takut Naira terlalu kenyang dan batuk sebab makanan tersebut adalah gorengan. Naira memanggil uwanya dengan sebutan Mamah. Jika dilihat dari data tersebut Naira banyak melafalkan konsonan [m] dan [n]. konsonan [m] merupakan bunyi nasal bilabial, sedangkan konsonan [n] merupakan bunyi lamino alviolar. Naira dalam mengucapkan bunyi nasal labial [m] dan lamino alviolar [n] sangat jelas. Pemerolehan bahasa Naira dalam konsonan [m] dan [n] mencerminkan tidak adanya gangguan dalam alat ucap. Penguasaan konsonan [m] dan [n] Naira sangat jelas, baik yang terdapat pada awal, tengah, dan akhir kata. Posisi awal konsonan [m] terdapat pada kata "mamah", "makan", dan posisi tengah konsonan [m] terdapat pada kata "emang". Selain itu konsonan [n] juga turut diucapkan oleh Naira pada posisi akhir kata yaitu terdapat dalam kata "makan", "babahan", dan "bawan". Naira selain menguasai konsonan [m] dan [n] juga menguasai bunyi 'ng' yang merupakan alofon dalam penulisan fonologisnya ialah ' $y$ ' bunyi ini disebut sebagai bunyi nasal bersuara yang menggunakan alat ucap pada bagian velar.

\section{Pemerolehan konsonan [g] dan [s]}

Pada percakapan dalam data konteks pembicaraannya adalah ketika Naira sedang bermain dengan kaka sepupunya yang ia sebut sebagai Kak Ambon. Naira dalam permainan seolah-olah melantunkan nada dalam permainan tersebut. Kata-kata yang Naira ucapkan mengandung konsonan [g] dan [s]. Konsonan [g] merupakan bunyi yang hambat yang berada pada area vellar. Sedangkan konsonan [s] merupakan bunyi frikatif yang berada di area dental atau alveolar. Konsonan [g] dan [s] yang dilafalkan oleh Naira yaitu kata "manggis". Naira melafalkan kata tersebut dengan sangat jelas, sehingga peneliti berasumsi bahwa Naira tidak ada gangguan pada alat ucapnya. Kata "manggis" terdiri dari fonem /m/, /a/, /n/, /g/, /g/, /i/, /s/. Huruf [g] berada pada tengah kata, dan huruf [s] berada pada akhir kata.

\section{Pemerolehan konsonan [h] dan [y]}

Pada percakapan dalam data konteks pembicaraannya adalah ketika Naira sedang menonton youtube dan di channel youtube tersebut menampilkan kartun variasi warna yang begitu banyak, sehingga pamannya menanyakan bahwa terdapat warna apa dalam kartus tersebut. Selain itu, konteks beralih pada permen Naira. Pamannya menanyakan apa rasa permen tersebut. Pemerolehan bahasa dari data di atas yaitu Naira mampu melafalkan bunyi konsonan [h] dan [y]. konsonan [h] terdapat pada kata "Hijo" dan "Merlah". Sedangkan, konsonan [y] terdapat pada kata "Meyon". Kata "hijo" terdiri dari fonem /h/, /i/, /j/, /o/. kata "Merlah" terdiri dari fonem $/ \mathrm{m} /$, /e/, /r/, /1/, /a/, /h/. Kata "Meyon" terdiri dari fonem $/ \mathrm{m} /$, , $/ \mathrm{e}, \mathrm{y} /, / \mathrm{o} /, / \mathrm{n} /$. Penguasaan bahasa Naira dalam pengucapan konsonan $[\mathrm{h}]$ dan $[\mathrm{u}]$ baik 
dan benar. Namun, Naira memiliki kesulitan dalam pengucapan konsonan [au], [r], dan [1], sehingga kata 'hijau' berubah menjadi 'hijo', kata 'merah' menjadi 'merlah', dan kata 'melon' menjadi 'meyon'. fonem $/ \mathrm{h} /$ merupakan bunyi frikatif yang berada pada area glotal, sedangkan fonem /y/ merupakan bunyi semivokal yang terletak pada area palatal.

Pemerolehan konsonan merupakan pemerolehan yang terkadang cukup sulit untuk diperoleh anak. Naira dalam pemerolehan konsonan tidak begitu menguasai seperti pada pemerolehan vokal. Naira masih sulit dalam melafalkan konsonan seperti [ny], [1], $[\mathrm{k}],[\mathrm{r}],[\mathrm{z}]$ dan masih banyak yang lainnya. Di usianya yang baru 2,5 tahun, Naira sudah cukup baik dalam penguasaan bunyi konsonan. Bunyi konsonan yang telah dikuasainya dan diperoleh hasil dari interaksi dengan orang lain diantaranya, $[\mathrm{b}],[\mathrm{d}],[\mathrm{m}]$, [n], [g], [s], [h], dan [y]. Pemerolehan bahasa ini di kuasai Naira sangat baik ketika ia berkomunikasi dengan orang lain. Dalam pengucapan konsonan yang telah dikuasainya, tidak terdapat hambatan baik dari segi bunyi maupun dari segi alat ucap.

\section{PENUTUP}

Pemerolehan bahasa dapat ditinjau dari aspek fonologis yang mana membahas mengenenai pemerolehan bunyi vokal dan bunyi konsonan. Aspek fonologis juga menjabarkan area yang menghasilkan bunyi-bunyi vokal dan konsonan. Dari data yang didapat seorang anak kecil berusia 2,5 tahun yang bernama Naira telah memperoleh bahasanya secara vokal dan konsonan dengan baik. Naira telah menguasai bunyi vokal /a/, /i/, /u/, /e/, dan /o/. Selain itu, Naira juga menguasai bunyi konsonan /b/, /d/, /m/, /n/, /g/, /s/, /h/, dan /y/. Naira mampu memperoleh dan menguasai bahasa dari segi fonem, baik fonem yang terletak pada awal, tengah, atau akhir sebuah kata.Maka dari penjabaran tersebut, penulis berharap semoga penelitian ini bisa bermanfaat bagi pembaca dan bisa dijadikan penelitian relevan untuk jenis penelitian lain yang sama.

\section{DAFTAR PUSTAKA}

Arsanti, Meilan. (2014). Pemerolehan Bahasa Pada Anak (Kajian Psikolinguistik). Semarang: Universitas Islam Sultan Agung. Jurnal PBSI Vol. 3 No. 2 tahun 2014.

Dardjowidjojo, Soenjono. (2010). Psikolinguistik: Pengantar Pemahaman Bahasa Manusia. Jakarta: Yayasan Obor Indonesia.

Gleason, Jean Barko and Nan

Bernstein Ratner. (1998).

Psycholinguistics. New York:

Harcout Brace College

Publisher.

Hamied, F.A. (1989). Keterpelajaran dalam Konteks Pemerolehan Bahasa. Jakarta: Penerbit Kanisius.

Klein. (1984). Learning to Stress. Journal of Child Language 11: 375-93/191. Indiana University.

Krashen, S and T. Terrel. (1983). The Natural Approuch: Language Acquisition in The Classroom. Oxford: Pergemon.

Kusuma, Alam Budi. (2016). Pemerolehan Bahasa Pertama Sebagai Dasar Pembelajaran Bahasa Kedua (Kajian Psikolinguistik). Yogyakarta: 
STAIMS Yogyakarta. Jurnal Komunikasi dan Pendidikan Islam, Vol. 2, No.2, Desember 2016.

Natsir, Nurasia. (2017). Hubungan Psikolinguistik dalam Pemerolehan dan Pembelajaran Bahasa. Makassar: Ilmu Administrasi, Sekolah Tinggi Ilmu Administrasi YAPPI Makassar, 2017. Vol. 10 No.1.

Noor, Juliansya. (2011). Metodologi Penelitian Skripsi, Tesis, Disertasi, dan Karya Ilmiah. Jakarta: Kencana.
Nuryani dan Dona Aji Karunia Putra. (2013). Psikolinguistik. Tangerang Selatan: Mazhab Ciputat.

Pateda, Mansoer. (1990). Aspek-Aspek Psikolinguistik. Yogyakarta: Nusa Indah.

Sigel, I and R Cocking. (2000). Cognitive Development from Childhood to Adolescence: A Constructivist Perspective. https://fccl.ksu.ru/papers/gp002.

Soehartono. (2005). Pengembangan Keterampilan Berbicara Anak Usia Dini. Jakarta: Departemen Pendidikan dan Kebudayaan. 